\title{
Analisis Kelayakan Usaha Penyulingan Minyak Nilam Di Kecamatan Salang
}

\author{
Yusnaidi ${ }^{1}$, Julisarnewi ${ }^{2}$ \\ Universitas Teuku Umar, Meulaboh \\ Email :yusnaidiyahya@gmail.com \\ Universitas Teuku Umar, Meulaboh
}

\begin{abstract}
This research was conducted at Salang Subdistrict in the District of Simeulu. It was aimed to evaluate the visibility to run patchouli oil distilation business. The data is primary data collected from the distilation plant at Salang Subdistrict in the District of Simeulu.The data was analized through Net Present Valie (NPV), Internal Rate Return (IRR), Net Benefit Cost Ratio (net B/C), Payback Priod (PP) in order to evaluate the investment visibility.

The result shows this business is visible to be done and invested. This conclusion is based on the result of the Net Present Valie (NPV), Internal Rate Return (IRR), Net Benefit Cost Ratio (net B/C), Payback Priod (PP) that shows positive result. Therefore the government should pay more attention to develop this business to grow and give more impact on community income.
\end{abstract}

Key words: patchouli oil, distilation business, investment, visibility study.

\section{Latar Belakang}

Indonesia merupakan negara beriklim tropis kaya akan beraneka ragam flora, berbagai jenis tanaman yang mempunyai banyak manfaat dapat tumbuh dengan mudah, salah satu diantaranya adalah tanaman yang dapat menghasilkan minyak atsiri. Indonesia memiliki potensi sebagai salah satu negara pengekspor minyak atsiri, seperti minyak nilam, kenanga, akar wangi, sereh wangi, cendana, pala, dan daun cengkeh. Beberapa daerah produksi minyak atsiri antara lain daerah Jawa Barat (sereh wangi, akar wangi, daun cengkeh, dan pala), Jawa Timur (kenanga dan cengkeh), serta daerah Jawa Tengah, Bengkulu, Aceh atau Sumatera utara sebagai penghasil minyak nilam (Puteh, 2005 : h.17).

Tanaman Nilam ( Progestemon Cablin Bent ) yaitu kelompok tanaman penghasil minyak atsiri, mempunyai prospek yang baik karena di samping harganya tinggi, juga sampai saat ini minyaknya belum dapat dibuat dalam bentuk sintesis. Kebutuhan dunia akan minyak atsiri yang berasal dari tanaman nilam saat ini berkisar $600-800$ ton/tahun. Sebagian besar kebutuhan ini disuplai dari Indonesia. Minyak nilam oleh Negara konsumen digunakan sebagai bahan pengikat dalam industri minyak wangi (parfum) atau dalam industri kosmetik lainnya.

Indonesia merupakan pemasok minyak nilam terbesar di dunia, yakni 90 persen dari kebutuhan dunia. Minyak nilam menyumbang lebih dari 50 persen ekspor minyak atsiri Indonesia, sehingga diharapkan dapat menjadi komoditas minyak Nilam unggulan di pasar ekspor. Negara yang akan bersaing di pasar dunia adalah RRC, Brasil, India, dan Malaysia (Junaedi, 2010: h.39). 
Provinsi Aceh merupakan salah satu daerah penghasil minyak nilam terbesar dan terbaik di Indonesia, hal ini dibuktikan dengan luas tanam terbesar di wilayah ini. Produksi nilai yang terus meningkat dari tahun ke tahun. Di samping itu, hasil uji laboratorium, minyak nilam yang berasal dari Provinsi Aceh masuk dalam katagori terbaik sedunia.

Kabupaten Simeulue merupakan salah satu Kabupaten di Aceh yang menghasilkan minyak nilam di Provinsi Aceh, tepatnya di Kecamatan Salang. Hal ini dibuktikan oleh adanya Pabrik Penyulingan Minyak Nilam “ Salang Atsiri”. Usahanya bergerak di bidang penyulingan minyak atsiri berbagai jenis tanaman diantaranya Nilam, Cengkeh, dan Pala (BPS Simeulue, 2012).

Namun rendahnya produksi dan mahalnya biaya dalam penyulingan minyak nilam tersebut. Sehingga perlu adanya perhatian khusus dalam peningkatan produksi tanaman nilam sehingga menjamin bahan baku dalam penyulingan minyak nilam yang ada di Kecamatan tersebut.

Di satu sisi, meningkatnya kebutuhan masyarakat nasional maupun internasional terhadap penggunaan minyak atsiri khususnya nilam, menuntut adanya perhatian secara produksi terhadap kebutuhan minyak atsiri tersebut. Di sisi lain, dipandang dari sisi ekonomi, maka diperlukan adanya analisis secara mendalam terhadap kelayakan usaha nilam. Hal ini dilakukan dengan tujuan untuk menganalisis secara mendalam terhadap kelayakan usaha tersebut. Sehingga dapat diketahui layak atau tidaknya untuk dikembangkan (Kasmir, dan Jakfar, 2009 : h.71).

\section{Metodologi Penelitian}

Metode penelitian yang peneliti gunakan adalah menggunakan pendekatan kuantitatif, yaitu pendekatan yang memusatkan perhatian pada perhitungan nilai yang ditunjukkan dengan nilai berupa angka dari suatu hasil penelitian .

Menindaklanjuti pernyataan tersebut, metode yang peneliti gunakan dalam penelitian ini adalah dengan menggunakan metode pendekatan kuantitatif. Dengan demikian, Penelitian ini diharapkan dapat meneliti lebih dalam mengenai Analisis Kelayakan Usaha Punyulingan Minyak Nilam di Kecamatan Salang Kabupaten Simeulue. B

Populasi dalam penelitian ini yaitu sebanyak tujuh usaha yang diambil dari 3 desa yang ada di Kecamatan Salang, namun dalam Penelitian ini Sampel yang diambil sebanyak jumlah dari populasi yaitu 7 Usaha Penyulingan Minyak Nilam, karena jumlah sampelnya kurang. Maka Teknik pengambilan data menggunakan Boring Sampling atau Sampel Jenuh.

Jenis data dalam penelitian ini merupakan data primer, data yang diambil secara langsung di lokasi penelitian. Dalam kaitannya dengan penelitian ini, observasi dilakukan untuk mengamati langsung di lokasi penelitian dengan cara penyebaran kuesioner.

Dalam penelitian ini, peneliti menggunakan 3 macam teknik pengumpulan data yaitu teknik observasi, wawancara dan kuesioner. Hasil data yang telah diperoleh, selanjutnya diolah dan dianalisis lebih mendalam dalam bentuk tabel dan uraian. Dengan tujuan Untuk mengetahui 
Analisis Kelayakan Usaha Punyulingan Minyak Nilam di Kecamatan Salang Kabupaten Simeulue, maka digunakan rumus sebagai berikut :

\section{a. $\quad$ Net Present Value (NPV)}

Untuk menghitung NPV, terlebih dahulu kita harus tau berapa PV kas bersihnya. PV kas bersih dapat dicari dengan jalan membuat dan menghitung dari Cash Flow usaha selama umur investasi tertentu, rumusnya di uraikan sebagai berikut :

Rumus : Nilai bersih sekarang (Net Present Value) $=$ NPV

$N P V=\prod_{t=1}^{n} \underline{B t-C t}$

Dimana :

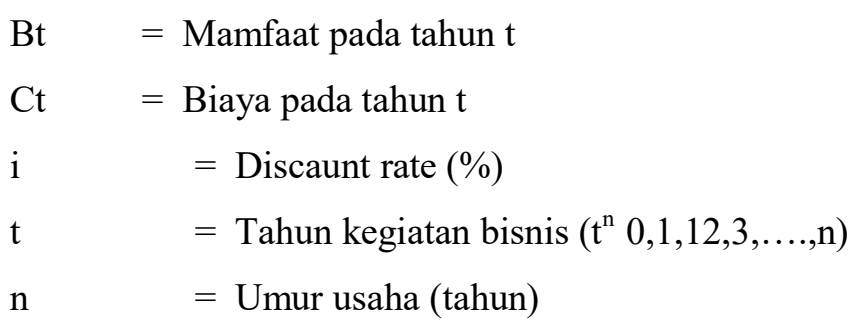

Kriteria kelayakan investasi berdasarkan NPV yaitu :

NPV $>0$, Artinya usaha sudah dinyatakan menguntungkan dan layak untuk dikembangkan.

$\mathrm{NPV}<0$, Artinya tidak menghasilkan nilai biaya yang dipergunakan dengan kata lain usaha tersebut merugikan dan sebaiknya tidak layak untuk dikembangkan.

$\mathrm{NPV}=0$, artinya usaha/proyek berada dalam keadaan BEP

\section{b. Internal Rate of Return (IRR).}

Kriteria layak atau tidak layak bagi suatu usaha adalah bila IRR lebih besar dari pada tingkat suku bunga yang berlaku saat usaha itu dilaksanakan. Rumusnya sebagai berikut :

Rumus:

$\mathrm{IRR}=\mathrm{i}_{1}+\frac{\mathrm{NPV} 1}{\mathrm{NPV} 1-\mathrm{NPV} 2}+(i 2-i 1)$

Dimana:

NPV1 $=$ NPV positif

NPV2 $=$ NPV negatif

$\mathrm{i} 1=$ Discount rate yang menghasilkan NPV positif

i2 = Discount rate yang menghasilkan NPV negatif

Kriteria:

Jika IRR > SOCC maka usaha dikatakan layak

IRR $=$ SOCC berarti usaha pada BEP

IRR $<$ SOCC dikatakan bahwa proyek/usaha tidak layak.

c. Net Benefit Cost Ratio (Net B/C) Perbandingan antara net benefit yang telah didiskon positif $(+)$ dengan net benefit yang telah didiskon negative. 
Rumus:

Net $B / C=\frac{\substack{n \\ t=0} \frac{B t-C t}{1+i t}}{\substack{n \\ t=0} \frac{B-C t}{1+i t}}$

Dimana:

$\mathrm{Bt}=$ Manfaat pada tahun $\mathrm{t}$

$\mathrm{Ct}=$ Biaya pada tahun $\mathrm{t}$

$\mathrm{N}=$ Umur bisnis

$\mathrm{I}=$ Discount rate $(\%)$

Jika:

Net $\mathrm{B} / \mathrm{C}>1$ (satu) berarti proyek (usaha) layak dikembangkan

Net $\mathrm{B} / \mathrm{C}<1$ (satu) berarti proyek tidak layak dikembangkan

$\mathrm{Net} B / \mathrm{C}=1$ (satu) berarti cash in flows = cash out flows

$\mathrm{TR}=\mathrm{TC}$

\section{d. Payback Period (PP)}

Payback Period (PP) merupakan teknik penilaian terhadap jangka waktu (periode) pengembalian investasi suatu proyek atau usaha. Perhitungan ini dapat dilihat dari perhitungan kas bersih (proceed) yang diperoleh setiap tahun. Nilai kas bersih merupakan penjumlahan laba setelah pajak ditambah dengan penyusutan (dengan catatan jika investasi 100 persen menggunakan modal sendiri).

Rumus:

$\mathrm{PP}=\frac{\text { Nilai Investasi }}{\text { Kas Masuk Bersih }} \times 1$ Tahun

Kriteria penilaian :

Jika payback period lebih pendek waktunya dari maxsimum payback period-nya maka ususlan investasi dapat diterima. Metode payback period ini cukup sederhana. Kelemahan utamanya yaitu metode ini tidak memperhatikan konsep nilai waktu dari uang di samping juga tidak memperhatikan aliran kas masuk setelah payback period. Jadi pada umumnya metode ini digunakan sebagai metode pendukung lain yang lebih baik.

Adapun definisi operasional variabel yang dipakai dalam penelitian ini adalah sebagai berikut:

1. Biaya adalah total uang yang telah dikeluarkan untuk memperoleh atau menghasilkan sesuatu dengan adanya suatu tujuan tertentu, di hitung dalam rupiah.

2. Biaya tetap adalah biaya yang secara total tidak berubah walaupun terjadi perubahan volume kegiatan, di hitung dalam rupiah.

3. Biaya berubah adalah biaya yang tidak tetap dan biaya ini selalu berubah secara proporsional dengan adanya aktifitas bisnis, di hitung dalam rupiah. 
4. Biaya produksi yaitu jumlah biaya yang dikeluarkan oleh produsen untuk menghasilkan sejumlah output untuk memperoleh keuntungan maksimum. di hitung dalam rupiah.

5. Harga adalah sejumlah uang yang diminta ditawarkan atau dibayarkan untuk suatu barang atau jasa, di hitung dalam rupiah.

6. Penerimaan adalah seluruh pendapatan yang diterima dari hasil penjualan barang pada tingkat harga tertentu, di hitung dalam rupiah.

7. Pendapatan adalah besarnya jumlah uang yang didapat atau besarnya penghasilan kerja yang didapat (Rp/bln), di hitung dalam rupiah.

\section{Hasil Penelitian dan Pembahasan}

Rata-rata penghasilan para pelaku bisnis penyulingan minyak nilam adalah:

Tabel: 1

Penghasilan Rata-rata Produksi Minyak Nilam di Kecamatan Salang Kabupaten Simeulue Periode 2010-2014 dalam jutaan rupiah (Rp)

\begin{tabular}{|c|c|c|c|c|c|c|c|c|}
\hline \multirow[b]{2}{*}{$\mathrm{N}_{0}$} & \multirow[b]{2}{*}{ Tahun } & \multicolumn{7}{|c|}{ Penghasilan Produksi Per Tahun } \\
\hline & & $\begin{array}{c}\text { Pabrik Salang } \\
\text { Atsiri }\end{array}$ & Pabrik Alafanta & Pabrik Along & Pabrik Budin & Pabrik Kalman & Pabrik M. Amin & Pabrik Jalimin \\
\hline 1 & 2010 & $30,500,000$ & 18.900 .000 & 19.000 .000 & 15.000 .000 & 8500 & 9.000 .000 & 7.000 .000 \\
\hline 2 & 2011 & $30,800,000$ & 20.000 .000 & 20.700 .000 & 25.000 .000 & 13.700 .000 & 12.600 .000 & 13.000 .000 \\
\hline 3 & 2012 & $301,000,000$ & 20.700 .000 & 20.900 .000 & 16.000 .000 & 18.000 .000 & 15.000 .000 & 14.500 .000 \\
\hline 4 & 2013 & $30,900,000$ & 30.000 .000 & 30.500 .000 & 20.000 .000 & 20.000 .000 & 9.000 .000 & 12.70 .000 \\
\hline 1 & 2014 & $40,000,000$ & 30.500 .000 & 30.900 .000 & 19.000 .000 & 19.000 .000 & 10.000 .000 & 15.000 .000 \\
\hline & umlah & $\operatorname{Rp} 433,200,000$ & Rp 120,100,000 & Rp 122,000,000 & Rp 95.000.000 & Rp 79.200.000 & Rp 55.600.000 & Rp 50.770.000 \\
\hline
\end{tabular}

Berdasarkan tabel diatas. Kecamatan Salang Kabupaten Simeulue memproleh penghasilan rata-rata produksi minyak nilam selama periode 2010 sampai 2014. Penghasilan ratarata produksi usaha minyak nilam pabrik Salang Atsiri sebesar Rp. 433,200,000 sedangkan pabrik Alafanta sebesar Rp.122,000,000 dan pabrik Along sebesar Rp. 120,100,000 dan milik Budin sebesar Rp. 95.000.000 dan milik Kalman sebesar Rp. 19.000.000 dan milik M. Amin sebesar Rp. 55.600.000 dan milik Jalimin sebesar Rp. 50.770.000 sebelum di potong pajak.

Nilai penghasilan yang ditunjukkan pada tabel diatas memperlihatkan prospek yang besar dari bisnis minya nilam ini. Namun demikian keberlanjutan dari kegiatan penyulingan ini membutuhkan pembinaan lebih lanjut dari para pemangku kepentingan. 
Pada tabel dibawah ini tertulis data jumlah modal dari masing-masing pengusaha penyulingan minyak nilam.

Tabel: 2

Modal Awal Usaha Penyulingan Nilam

\begin{tabular}{|l|l|l|l|}
\hline No & Nama Usaha & Jumlah Modal Awal & Asal Modal Awal \\
\hline 1 & Salang Atsiri & 100.000 .000 & Pinjaman \\
\hline 2 & Alafanta & 85.000 .000 & Pinjaman \\
\hline 3 & Along & 90.000 .000 & Pinjaman \\
\hline 4 & Budin & 75.000 .000 & Modal Sendiri \\
\hline 5 & Kalman & 88.000 .000 & Modal Sendiri \\
\hline 6 & M.Amin & 87.000 .000 & Modal Sendiri \\
\hline 7 & Jalimin & 75.000 .000 & Modal Sendiri \\
\hline
\end{tabular}

Berdasarkan tabel diatas, menunjukkan bahwa Gampung Karya Bakti diambil hanya satu pabrik Salang Atsiri memiliki modal investasi awal yaitu sebanyak Rp 100.000,000. Untuk usaha penyulingan minyak nilam di Gampung Mata Air dimbil dalam tiga pabrik dari masing-masing pabrik, pabrik Alafanta memiliki modal investasi awal sebesar Rp. 85,000,000., dan milik Budin juga memiliki modal investasi awal sebesar Rp. 75.000,000., serta milik Kalman memiliki juga modal investasi awal sebesar Rp. 88,000,000 Sedangkan untuk Gampung Panten Lawe dimbil dalam tiga pabrik dari masing-masing pabrik, dan pabrik Along juga memiliki modal investasi awal Rp. 90,000,000. Dan milik M. Amin memiliki modal investasi awal sebesar Rp. 87.000.000. dan milik Jalimin juga memiliki modal investasi awal sebesar Rp 75.000,000

Adapun penghasilan rata-rata produksi Penyulingan Minyak Nilam di Kecamatan Salang Kabupaten Simeulue dapat kita lihat pada tabel 3 berikut.

Tabel: 3

Penghasilan Rata-rata Produksi Minyak Nilam di Kecamatan Salang Kabupaten Simeulue Periode 2010-2014 dalam jutaan rupiah (Rp)

\begin{tabular}{|c|c|c|c|c|c|c|c|c|}
\hline \multirow[b]{2}{*}{$\mathrm{N}_{0}$} & \multirow[b]{2}{*}{ Tahun } & \multicolumn{7}{|c|}{ Penghasilan Produksi Per Tahun } \\
\hline & & $\begin{array}{c}\text { Pabrik Salang } \\
\text { Atsiri }\end{array}$ & Pabrik Alafanta & Pabrik Along & Pabrik Budin & Pabrik Kalman & Pabrik M. Amin & Pabrik Jalimin \\
\hline 1 & 2010 & $30,500,000$ & 18.900 .000 & 19.000 .000 & 15.000 .000 & 8500 & 9.000 .000 & 7.000 .000 \\
\hline 2 & 2011 & $30,800,000$ & 20.000 .000 & 20.700 .000 & 25.000 .000 & 13.700 .000 & 12.600 .000 & 13.000 .000 \\
\hline 3 & 2012 & $301,000,000$ & 20.700 .000 & 20.900 .000 & 16.000 .000 & 18.000 .000 & 15.000 .000 & 14.500 .000 \\
\hline 4 & 2013 & $30,900,000$ & 30.000 .000 & 30.500 .000 & 20.000 .000 & 20.000 .000 & 9.000 .000 & 12.70 .000 \\
\hline 5 & 2014 & $40,000,000$ & 30.500 .000 & 30.900 .000 & 19.000 .000 & 19.000 .000 & 10.000 .000 & 15.000 .000 \\
\hline & umlah & Rp 433,200,000 & Rp 120,100,000 & $\operatorname{Rp} 122,000,000$ & Rp 95.000.000 & Rp 79.200.000 & $\operatorname{Rp} 55.600 .000$ & Rp 50.770.000 \\
\hline
\end{tabular}


Tabel: 4

Modal Kerja Usaha Minyak Nilam di Kecamatan Salang Kabupaten Simeulue Periode 2010-2014 dalam jutaan rupiah (Rp)

\begin{tabular}{|c|c|c|c|c|c|c|c|c|}
\hline No & Tahun & $\begin{array}{c}\text { Pabrik Salang } \\
\text { Atsiri }\end{array}$ & Pabrik Alafanta & Pabrik Along & Pabrik Budin & Pabrik Kalman & Pabrik M. Amin & Pabrik Jalimin \\
\hline 1 & 2010 & 10.600 .000 & $7,500.00$ & $8,500.00$ & 7.500 .000 & 3.000 .000 & 3.500 .000 & 2.200 .000 \\
\hline 2 & 2011 & 11.500 .000 & 8.000 .000 & 10.600 .000 & 9.000 .000 & 4.500 .000 & 5.700 .000 & 3.500 .000 \\
\hline 3 & 2012 & 13.000 .000 & 11.000 .000 & 11.000 .000 & 8.000 .000 & 5.000 .000 & 6.000 .000 & 5.900 .000 \\
\hline 4 & 2013 & 14.500 .000 & 12.000 .000 & 12.900 .000 & 6.000 .000 & 7.000 .000 & 3.900 .000 & 4.000 .000 \\
\hline 5 & 2014 & 15.700 .000 & 13.000 .000 & 13.000 .000 & 5.000 .000 & 6.500 .000 & 4.000 .000 & 5.000 .000 \\
\hline Jumlah & Rp 65,300,000 & Rp 51,500,000 & Rp 38,000,000 & Rp 35.500.000 & Rp 26.000.000 & Rp 23.100.000 & Rp 20.600.000 \\
\hline
\end{tabular}

Berdasarkan tabel diatas. Kecamatan Salang Kabupaten Simeulue memproleh penghasilan rata-rata produksi minyak nilam selama periode 2010 sampai 2014. pennghasilan rata-rata produksi usaha minyak nilam pabrik Salang Atsiri sebesar Rp. 65,300,000 sedangkan pabrik Alafanta sebesar Rp. 51,500,000 dan pabrik Along sebesar Rp. 38,000,000. dan milik Budin sebesar Rp,35.500.000 dan milik Kalman sebesar Rp. 26.000.000 dan milik M. Amin sebesar Rp, 23.100.000 dan milik Jalimin sebesar Rp. 20.600.000.

Harga produksi minyak nilam yang dijual oleh para pemilik pabrik kepada konsumen dari tahun 2010 seharga Rp. 250.000 ribu, dan selanjutnya tahun 2011 seharga Rp 300.000 ribu, selanjutnya tahun 2012 turun harganya menjadi Rp. 240.000 ribu, dan seterusnya tahun 2013 naik lagi menjadi Rp. 500.000 ribu, dan selanjutnya tahun 2014 juga naik menjadi Rp. 900.000 ribu.

Sementara itu jumlah produksi yang dihasilkan dalam per tahun dapat kita lihat tabel di bawah ini:

Tabel:5

Produksi Minyak Nilam yang di Hasilkan dalam per tahun.

\begin{tabular}{|c|c|c|c|c|c|c|c|c|}
\hline No & Tahun & $\begin{array}{c}\text { Pabrik } \\
\text { Salang } \\
\text { Atsiri }\end{array}$ & $\begin{array}{c}\text { Pabrik } \\
\text { Atalafan }\end{array}$ & $\begin{array}{c}\text { Pabrik } \\
\text { Along }\end{array}$ & $\begin{array}{c}\text { Pabrik } \\
\text { Budin }\end{array}$ & $\begin{array}{c}\text { Pabrik } \\
\text { Kalman }\end{array}$ & $\begin{array}{c}\text { Pabrik } \\
\text { M.Amin }\end{array}$ & $\begin{array}{c}\text { Pabrik } \\
\text { Jalimin }\end{array}$ \\
\hline 1 & 2010 & $250 \mathrm{~kg}$ & $150 \mathrm{~kg}$ & $180 \mathrm{~kg}$ & $150 \mathrm{~kg}$ & $120 \mathrm{~kg}$ & $100 \mathrm{~kg}$ & $170 \mathrm{~kg}$ \\
\hline 2 & 2011 & $350 \mathrm{~kg}$ & $270 \mathrm{~kg}$ & $240 \mathrm{~kg}$ & $230 \mathrm{~kg}$ & $200 \mathrm{~kg}$ & $250 \mathrm{~kg}$ & $240 \mathrm{~kg}$ \\
\hline 3 & 2012 & $380 \mathrm{~kg}$ & $350 \mathrm{~kg}$ & $380 \mathrm{~kg}$ & $300 \mathrm{~kg}$ & $360 \mathrm{~kg}$ & $300 \mathrm{~kg}$ & $350 \mathrm{~kg}$ \\
\hline 4 & 2013 & $650 \mathrm{~kg}$ & $440 \mathrm{~kg}$ & $490 \mathrm{~kg}$ & $500 \mathrm{~kg}$ & $300 \mathrm{~kg}$ & $390 \mathrm{~kg}$ & $300 \mathrm{~kg}$ \\
\hline 5 & 2014 & $800 \mathrm{~kg}$ & $590 \mathrm{~kg}$ & $600 \mathrm{~kg}$ & $420 \mathrm{~kg}$ & $480 \mathrm{~kg}$ & $370 \mathrm{~kg}$ & $490 \mathrm{~kg}$ \\
\hline \multicolumn{2}{|c|}{ Jumlah } & $2.430 \mathrm{~kg}$ & $1.800 \mathrm{~kg}$ & $1.890 \mathrm{~kg}$ & $1.600 \mathrm{~kg}$ & $1.460 \mathrm{~kg}$ & $1.410 \mathrm{~kg}$ & $1.550 \mathrm{~kg}$ \\
\hline
\end{tabular}


Berdasarkan tabel diatas, Produksi yang dihasilkan dalam per tahun, pertama untuk pabrik Salang Atsiri menghasilkan sebanyak 2.430kg minyak. Dan untuk pabrik Alafanta menghasilkan $1.800 \mathrm{~kg}$ minyak, selanjutnya pabrik Along juga menghasilkan $1.890 \mathrm{~kg}$ minyak, selanjutnya pabrik milik Budin juga menghasilkan 1.600kg minyak, selanjutnya pabrik milik Kalman juga menghasilkan $1.460 \mathrm{~kg}$ minyak, selanjutnya pabrik milik M.Amin juga menghasilkan $1.410 \mathrm{~kg}$ minyak, selanjutnya pabrik milik Jalimin juga menghasilkan $1.550 \mathrm{~kg}$ minyak.

Pertama untuk pabrik Salang Atsiri sekali penyulingan sebanyak 1 ton bahan baku nilam kering, dan untuk pabrik Alafanta sekali penyulingan sebanyak $800 \mathrm{~kg}$ bahan baku nilam kering, selanjutnya pabrik Along sekali penyulingan $800 \mathrm{~kg}$ bahan baku nilam kering, selanjutnya pabrik milik Budin sekali penyulingan $700 \mathrm{~kg}$ bahan baku nilam kering, selanjutnya pabrik milik Kalman sekali penyulingan sebanyak $700 \mathrm{~kg}$ bahan baku nilam kering, selanjutnya pabrik milik M.Amin sekali penyulingan $800 \mathrm{~kg}$ bahan baku nilam kering, selanjutnya pabrik milik Jalimin sekali penyulingan sebanyak 1 ton bahan baku nilam kering. Selanjutnya untuk sekali produksi/penyulingan akan menghasikan minyak nilam sebanyak $35 \mathrm{~kg}$. dan untuk produksi dalam satu tahun sebanyak 5 kali produksi atau penyulingan.

Berdasarkan hasil Penelitian bahwa semua usaha penyulingan minyak nilam yang ada di Kecamatan Salang menunjukan layak untuk dikembangkan. Hal ini dapat dilihat pada tabel sebagai berikut:

Tabel: 6

Hasil Pembahasan Dari 7 (Tujuh) Usaha Penyulingan Minyak Nilam di Kecamatan Salang Kabupaten Simeulue.

\begin{tabular}{|l|l|l|l|l|l|l|}
\hline No & $\begin{array}{l}\text { Nama } \\
\text { Pemilik } \\
\text { Usaha }\end{array}$ & NPV & IRR & B/C & PP & Keterangan \\
\hline 1 & Salang Atsiri & $220,780,200$ & $3,659 \%$ & 6,59 & 96 & Layak \\
\hline 2 & Alafanta & $41,114,600$ & $1,097 \%$ & 2,34 & 14.32 & Layak \\
\hline 3 & Along & $39,078,300$ & $472 \%$ & 3,55 & 11.30 & Layak \\
\hline 4 & Budin & 360.545 .000 & $1,24 \%$ & 2.56 & 9.64 & Layak \\
\hline 5 & Kalman & 313.516 .000 & $2.69 \%$ & 3,05 & 16.18 & Layak \\
\hline 6 & M.Amin & 2034.73000 & $2.97 \%$ & 2.40 & 17,17 & Layak \\
\hline 7 & Malim Amin & 249.832 .000 & $1.24 \%$ & 3,04 & 15,71 & Layak \\
\hline
\end{tabular}


Berdasarkan tabel diatas maka dapat dilihat bahwa Usaha Penyulingan Minyak Nilam pabrik Salang Atsiri nilai NPV layak diterima, karena nilai NPV bernilai positif . dan nilai IRR juga layak diterima, hasil analisisnya B/C juga layak diterima, dan nilai PP juga layak diterima.

\section{Kesimpulan}

Usaha Penyulingan Minyak Nilam pabrik Alafanta nilai NPV layak diterima, karena nilai NPV bernilai positif. dan nilai IRR juga layak diterima, hasil analisisnya B/C juga layak diterima, dan nilai PP juga layak diterima. Usaha Penyulingan Minyak Nilam pabrik Along nilai NPV layak diterima, karena nilai NPV bernilai positif. dan nilai IRR juga layak diterima, hasil analisisnya B/C juga layak diterima, dan nilai PP juga layak diterima. Usaha Penyulingan Minyak Nilam pabrik Budina nilai NPV layak diterima, karena nilai NPV bernilai positif. dan nilai IRR juga layak diterima, hasil analisisnya B/C juga layak diterima, dan nilai PP juga layak diterima. Usaha Penyulingan Minyak Nilam pabrik Kalman nilai NPV layak diterima, karena nilai NPV bernilai positif. dan nilai IRR juga layak diterima, hasil analisisnya B/C juga layak diterima, dan nilai PP juga layak diterima. Usaha Penyulingan Minyak Nilam pabrik M.Amin nilai NPV layak diterima, karena nilai NPV bernilai positif. Nilai IRR juga layak diterima, hasil analisisnya B/C juga layak diterima, dan nilai PP juga layak diterima. Usaha Penyulingan Minyak Nilam pabrik Malim Amin nilai NPV layak diterima, karena nilai NPV bernilai positif, dan nilai IRR juga layak diterima, hasil analisisnya $\mathrm{B} / \mathrm{C}$ juga layak diterima, dan nilai PP juga layak diterima.

Berdasarkan penelitian yang telah dilakukan dapat diberikan beberapa saran sebagai berikut : 
- Penelitian ini hanya membahas beberapa aspek dari kelayakan, sehingga diperlukan Penelitian lebih lanjut yang membahas semua aspek-aspek lain dari kelayakan untuk mendapatkan keakuratan dari penilaian suatu usaha.

- Penelitian ini hanya menganalisa kelayakan usaha berdasarkan rencana anggaran yang telah ditetapkan, untuk Penelitian selanjutnya membahas lebih rinci tentang kelayakan usaha di Kecamatan Salang Kabupaten Simeulue. 


\section{Daftar Pustaka}

Firdaus. Muhammad. 2008. Manajemen Agriusaha. PT. Bumi Aksara. Jakarta.

Halimah, Diana Pramifta Putri; Zetra, Yulfi. 2010, "Minyak Atsiri dari Tanaman Nilam (Pogostemon Cablin Bent. ) Melalui Metode Fermentasi dan Hidrodestilasi Serta Uji Bioaktfitasnya.

Junaedi A,2010. Uji Asal Sumber Bibit Nilam (Pogostemon cablin Benth.) Di Pasaman Barat Sumatera Barat. Balai Penelitian Hutan Penghasil Serat, Kuok.

Johan, Suito. 2011. Studi kelayakan pengembangan usaha. Graha Ilmu. Yogyakarta.

Kasmir, dan Jakfar. 2009. Studi kelayakan usaha. Edisi kedua, Cetakan ke-6. Kecana. Jakarta.

Kadariah, dkk. 2006. Pengantar Evaluasi Proyek. Edisi Revisi. LP FE UI. Jakarta.

Komaruddin, 2006, Ensiklopedia Manajemen, Edisi ke-5, Jakarta : Bumi Aksara.

Nurlelasari,dkk. Peningkatan Kadar Patchouli Alkohol Pada Minyak Nilam Melalui Teknik Kultur Jaringan..No.003/SP2H/PP/DP2M/III/2007 . Tanggal 29 Maret 2007.

Puteh A., 2005. Potensi dan Kebijakan Pengembangan Nilam di Provinsi Nanggroe Aceh Darussalam, Perkembangan teknologi TRO Vol. XVI.

Rosman, R. dan Hermanto. 2008. Aspek iklim dan lahan untuk pengembangan Nilam di Nangroe Aceh Darussalam. Perkembangan Teknologi TRO 16 (2) : 21 - 28. Balai Penelitian Tanaman Rempah dan Obat. Bogor.

Subroto, Toto. 2009. Budidaya dan Penyulingan Minyak Nilam. Bandung: PT Pribumi Mekar. ISBN 978-979-9148-67-4.

Soeharto. (2005). Studi Kelayakan Proyek Industri. Erlangga, Jakarta.

Soeharto, Iman. 2005. Manajemen Proyek. Edisi Kedua, Jilid 1. Erlangga. Jakarta.

Sukirno, Sadono. (2005). Pengantar Teori Mikro Ekonomi. Raja Grafindo Perseda, Jakarta Tjitrosoepomo, Gembong. 2005. Morfologi Tumbuhan. Jogjakarta: Gadjah Mada University Press.

Umar, Husein 2009. Studi Kelayakan Usaha. Edisi 3 Revisi. Gramedia Pustaka Utama. Jakata.

Wahyudi, agus; Ermiati. 2012. "Proposal Pengembanagan Industri Minyak Nilam Di Indonesia". Bunga Rampai Inovasi Tanaman Atsiri Indonesia. 